\title{
Navigating the Landscape of Pedagogical Training: The Journeys of Three Mathematics Graduate Students
}

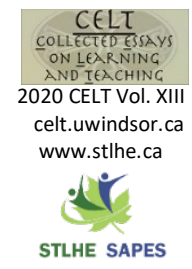

\author{
Matt Coles, Fok-Shuen Leung, Vanessa Radzimski, Pam Sargent \\ University of British Columbia, University of the Fraser Valley, Yale University
}

This article describes the landscape of teaching assistantships (TAships) in the Mathematics Department of a large, public research institution. First, we present visualized data describing the terrain for all mathematics graduate students. Second, we focus on three specific journeys through that terrain. We employ an autoethnographical research methodology to analyze the pedagogical paths of three recent graduates through written reflection. We highlight some surprising themes that emerge, identify key moments in each reflection, and make three proposals, applicable in broader contexts, in order to capture and confer their benefits.

Dans notre article, nous traçons le portrait de l'assistanat d'enseignement dans le département de Mathématique d'un grand établissement public de recherche. Tout d'abord, nous présentons des données sous forme visuelle de manière à décrire la réalité sur le terrain des étudiants en mathématique des cycles supérieurs. Ensuite, nous portons notre attention sur trois parcours particuliers. Au moyen de réflexions menées par écrit, nous utilisons une méthodologie de recherche autoethnographique afin d'analyser le parcours pédagogique de trois nouveaux diplômés. Nous soulignons certains thèmes surprenants, nous dégageons les moments clés de chaque réflexion, puis nous énonçons trois propositions - lesquelles peuvent être utilisées dans un contexte plus large - et nous en présentons les avantages.

$\mathrm{R}$ esearch and teaching are the foci of any academic career. While the research journey of a junior scholar may vary, it is generally marked by key features-qualification and candidacy exams, regular guidance by a senior scholar, an oral defense, and so on. On the other hand, the landscape of teaching assistantships (TAships) and pedagogical training is more $a d$ hoc and can vary dramatically between institutions (Boyle \& Boice, 1998; Silverman, 2003). Although there is a wealth of literature on the pedagogical preparation of $\mathrm{K}-12$ teachers, there is limited research on the development of junior researchers as teachers (Speer, Gutman, \& Murphy,
2005). The need for this research, however, is evident (Musgrave \& Carlson, 2017).

This study focuses on the landscape of TAships and three specific TA journeys of recent graduate students at the University of British Columbia (UBC). All three TAs are now in faculty or postdoctoral positions that combine teaching and mathematics education research. UBC is a large, public research institution. It has two campuses; this study took place at the larger, Vancouver campus, which has around 45,000 undergraduate students and 10,000 graduate students. The Mathematics Department has around 70 faculty members and 100 graduate students. Firstyear Mathematics courses have a combined 
enrolment of over 6,000 students each year. The Department plays a large "service teaching" role; that is, most students taking Mathematics courses are not Mathematics majors.

The Mathematics Department at UBC has an extensive graduate TA training program. In her study of instructor training programs for mathematics TAs, Ellis (2014) lists the following features of successful programs:

1. Successful programs have in-service as well as pre-service components.

2. Successful programs are situated in the particular context of mathematics instruction.

3. Successful programs include "approximations of practice" and feedback.

4. Successful programs are supported by the department and institution.

5. Successful programs support innovative instructional practices.

Pedagogical training at UBC comprises all five features (Bruni \& Leung, 2020). All TAs undergo a two-day pre-service orientation session. TAs who wish to teach are required to take a term-long, creditbearing course on teaching. TAs who teach are also able to join an Instructor Support Group that encourages reflection and innovation in teaching. Finally, the Mathematics Department offers threeday-long custom-made Instructional Skills Workshops (Dawson et al., 2014).

We embarked on this project with the goal of providing TAs in the Mathematics Department a better-defined experience with more opportunities for growth. In section 2, we describe the different types of TAships and illustrate the different pedagogical pathways between them. In section 3, we outline the autoethnographical research methodology employed and provide the three participantresearchers' autoethnographical reflections. In section 4 , we discuss the themes that emerged from the reflections and make corresponding proposals. Finally, in section 5, we conclude by emphasizing the importance of considering TAships both from a bird's-eye, program-level view, and from the view of individual TAs with distinct and diverse experiences.

\section{The Landscape of TAships: A Bird's-Eye View}

The size of the department's teaching role demands a substantial TA program. Each year, over 200 graduate TAships are assigned. A large number of undergraduate TAships are also assigned, but our focus is on the graduate experience. Most graduate students hold TAships in every year of their degree. TA duties vary widely. We categorize them into the seven types (see Table 1 on the following page). These are ordered by prevalence, with the most common TAships first.

Figure 1 is a visualization of the "landscape" of TAships. It was generated by data on all 1,096 TAships held by 146 graduate TAs in the UBC Mathematics Department in the four full academic years from 2015 to 2019.

Figure 1

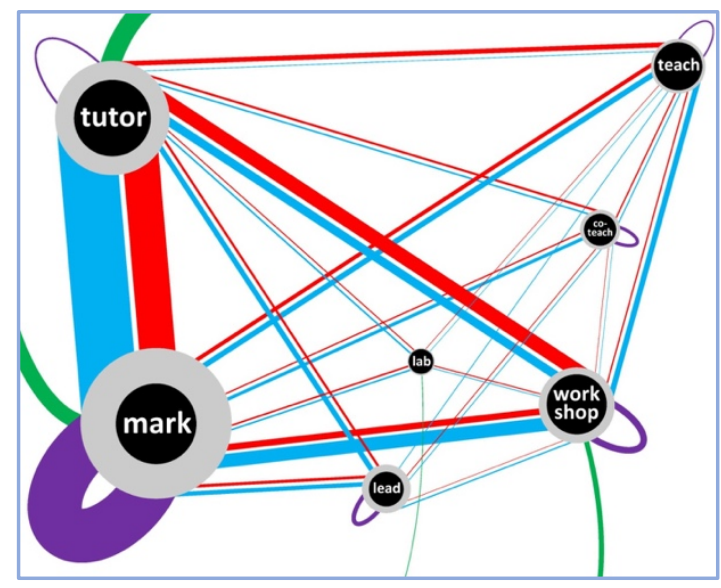

A bird's-eye view of the landscape of TAships.

Each node represents a TAship type. The area represents the number of TAships, and the inner area represents the number of individual TAs. For example, 506 marking TAships were assigned to 139 individual TAs.

Paths between nodes represent TAs moving from one TAship to another. For example, a TA assigned to mark in Term 1 and facilitate workshops 


\begin{tabular}{|c|c|c|}
\hline \multicolumn{3}{|r|}{$\begin{array}{l}\text { Table } 1 \\
\text { Types of TAships }\end{array}$} \\
\hline Type & $\begin{array}{l}\text { Figure } 1 \\
\text { Label }\end{array}$ & Description \\
\hline $\begin{array}{l}\text { Drop-in } \\
\text { tutoring }\end{array}$ & Tutor & $\begin{array}{l}\text { TAs have scheduled hours at a drop-in help centre for first- and } \\
\text { second-year students. Most of the work is one-on-one discussions } \\
\text { with students working on homework assignments. }\end{array}$ \\
\hline Marking & Mark & TAs grade written assignments in upper-year courses. \\
\hline $\begin{array}{l}\text { Workshop } \\
\text { Facilitation }\end{array}$ & Workshop & $\begin{array}{l}\text { TAs run weekly, 80-minute supplementary problem-solving sessions } \\
\text { for } 25-35 \text { students. Lesson plans are generally provided. }\end{array}$ \\
\hline Teaching & Teach & $\begin{array}{l}\text { TAs teach their own section of a first- or second-year course, } \\
\text { containing between } 80 \text { and } 120 \text { students. Logistical support-for } \\
\text { example, handling add/drop requests-is provided, and lecture notes } \\
\text { are occasionally provided. }\end{array}$ \\
\hline Co-teaching & Co-Teach & $\begin{array}{l}\text { TAs teach twice-weekly small classes of } 25-35 \text { students. Different } \\
\text { from workshops, these small classes introduce new material. In some } \\
\text { cases, lesson plans are still provided. }\end{array}$ \\
\hline $\begin{array}{l}\text { Lab } \\
\text { facilitation }\end{array}$ & Lab & $\begin{array}{l}\text { TAs run weekly, 50-minute MATLAB problem-solving sessions of } 25- \\
35 \text { students. Lesson plans are provided. }\end{array}$ \\
\hline Leadership & Lead & $\begin{array}{l}\text { This is a catch-all term for TAships with significant } \\
\text { administrative components. For example, head workshop TAs } \\
\text { organize schedules and run weekly catch-up meetings for other } \\
\text { TAs. }\end{array}$ \\
\hline
\end{tabular}

in Term 2 would move along the path from the "mark" node to the "workshop" node. There are almost always two paths between each pair of nodes, and a TA located at one node moves to the other node along the right-hand path. The sole exception is that there is only one path from "lead" to "teach"; no TAs had teaching TAships followed immediately by leadership TAships. The more TAs that move along a path, the wider it is. For example, 49 TAs moved from marking to workshops while only 22 TAs moved in the opposite direction, from workshops to marking.

Loops are paths from a node to itself, representing TAships that are immediately repeated. For example, of the 506 marking TAships, 190 of them were assigned to TAs who had just completed another marking TAship.

Finally, approach paths from the edge of the figure are paths to first TAships. For example, 54 TAs were assigned marking as their first TAship in their graduate degree.

\section{The Landscape of TAships: Three Views from the Ground}

\section{The Importance of Experience}

The landscape visualized in this section encapsulates a great deal of data but little insight into the actual 
experience of a TA. Indeed, the density of paths illustrates the enormous diversity of TA trajectories. Ultimately, we wanted to understand the individual experience better. How does the journey feel? How does it change what we value? What experiences are the most personally consequential?

Qualitative research methods are more suited to these questions, being designed, in part, to help researchers understand human experience (Bogdan \& Bicklen, 2007). Here, an autoethnographical approach is appropriate. Ellis (2004) defines ethnography as the study of people and culture. This research methodology is commonly used in studies about cultural groups different than those of the researcher. In autoethnography, the distance between researcher and subject is collapsed: the researcher is the participant and the researcher's experiences are the data. This method has been used in academic fields such as sociology since at least 1979 (Hayano, 1979). Narratives of personal experience lie at its centre (Ellis \& Bochner, 2000).

\section{Method}

We (the three participant-researchers) began our graduate degrees in mathematics at UBC around the same time. We have all recently graduated and taken faculty or postdoctoral positions that combine teaching and mathematics education research.

This study emerged out of informal conversations focused on capturing our own TA experiences: What was it really like? Were there any events that, in retrospect, changed our journeys or our aspirations? Guided by Sarah Wall's instruction that "Autoethnography is a form of writing that should allow readers to feel the dilemmas, think with a story rather than about it" (Wall, 2008, p. 44), we each wrote two reflections. The first reflections started with the following prompts:

1. How has my teaching philosophy changed from when I entered grad school?

2. What were the key influences along my journey?
The second reflections were prompted by themes that the fourth author, who is not a participantresearcher in the auto-ethnographical sense, identified from the initial reflections: innovation (Vanessa), mentorship (Pam) and expectations (Matt). Finally, we used the knowledge gained from reflecting on our personal experiences to identify changes that could result in an enriched TA experience for graduate students in general.

In the following sections, each participantresearcher speaks in turn, situating their journey in the larger landscape described in The Landscape of TAships: Three Views from the Ground. That landscape is reproduced in Figure 2, with the participant-researchers' paths highlighted.

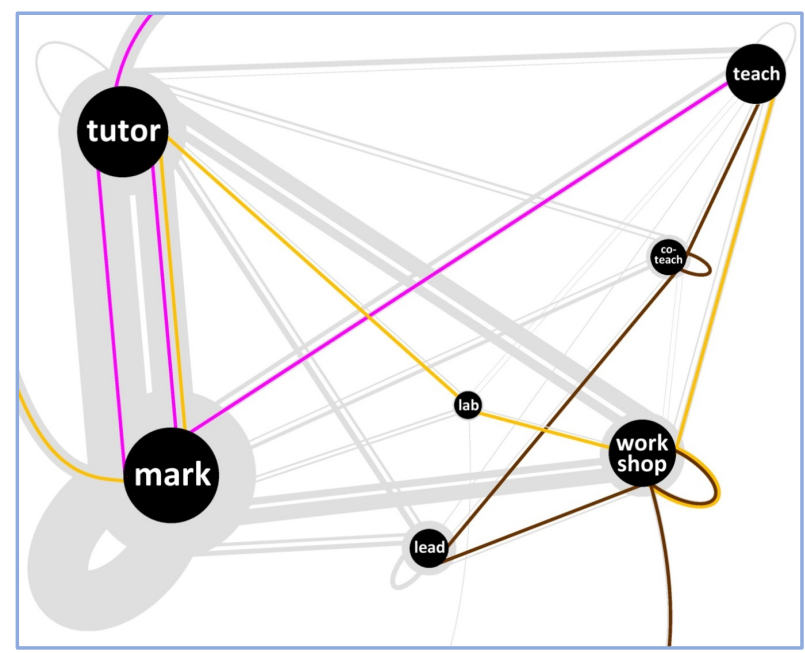

Figure 2

Three journeys on the landscape of TAships

\section{Reflections}

\section{Vanessa: An Opportunity to Grasp onto Something New}

My journey in the landscape is marked in pink in Figure 2. I was assigned to two tutoring TAships and two marking TAships before teaching a first-year differential calculus course. This is a relatively common journey; tutoring and marking TAships account for 801 of the 1096 TAships visualized in Figure 1. In my first reflection, I describe the conflict between my impulse to teach creatively and the 
attenuating force of tradition-to teach "the way I was taught:"

Among all the mathematics courses

I took in my undergraduate career, every single class was given as a lecture. I never experienced any pedagogical techniques besides the lecture; no group work, no worksheets, no think-pair-share, no presentations, no working on problems in class. I spent every class sitting quietly, vigorously writing notes, and asking the occasional question if and when the opportunity presented itself. This trend continued when I transitioned to graduate studies. On top of having courses taught in the traditional way, all of my courses were taught by the traditional figure of a math professor. All but one of the twenty plus faculty members who taught me mathematics were men. I entered my pedagogical journey with one side of my mind thinking I should teach the way I was taught, while the other side thought of the other lessons in my life that were grounded in experience.

Later in my journey, something happened that lessened the force of tradition-I found a community of practice that encouraged innovation:

Two semesters into my graduate studies, I found myself amongst a group of graduate students led by a faculty member, with the common goal of enhancing the learning experiences of their students. At this point, my mind was opened to new techniques and strategies to get students active and thinking inside the classroom. I was constantly hearing how much fun it was to teach with the non-traditional style and witnessed first-hand students' learning gains when visiting my peers' classes. Upon trying some techniques, I noticed not only how much my students enjoyed them, but how informative it was to know how my students were digesting new content. I found myself veering away from the traditional more and more, finding my own voice and style as a young woman teaching university mathematics.

The community was liberating because I felt supported in it. As I describe in my second reflection, the support gave me confidence:

I think having someone take an interest in me helped give me some confidence to pursue endeavours on my own. I know many people who like to go with the flow and fit within the identity that they think they are supposed to fit within. Actually, I think this was me when I first came to grad school. I was surrounded by all of these young mathematicians who were very driven to become better mathematicians. [...] I tried so hard to be like my fellow grad students in my first year, living and breathing mathematics every waking moment. I stopped dancing, I stopped exercising, I stopped teaching, I stopped everything else that used to give me joy. This took a major toll on my mental health in my first year, but in trying to be like my friends, impress my supervisor and professors, I continued to drive myself into the ground mentally, physically, and emotionally. In this sense, I think having someone reach 
out was an opportunity to grasp onto something new that could maybe get me out of the hole I was in.

\section{Pam: The Opportunity to Make Mistakes}

My journey in the landscape is marked in brown in Figure 2. It began with a workshop facilitation TAship. This is unusual: the most common first assignments - the widest approach paths - are to marking and tutoring TAships. I spent two years as a workshop TA before taking on the head workshop TA position. After that, I co-taught small classes before teaching a summer offering of an integral calculus course. I begin my first reflection by describing my undergraduate experience in a local community college as "one of the best decisions I've ever made:"

There was a lot of interaction between the instructors and the students, and there was a strong sense of community amongst the students. We were able to let our guards down when working together, and everything became a lot more fun (and less stressful).

My Math instructor was particularly open and encouraging:

I can clearly remember going to his office to ask him why my solution to a homework problem was wrongtwo of my fellow students had done it another way and gotten a different answer, and I couldn't see where I had gone wrong. He challenged me to believe in my own abilities - as it happened, I had only assumed I was wrong because I was outnumbered, but what I'd done was correct.

My experience of graduate school, on the other hand, was similar to Vanessa's:
My experience in graduate school was a bit different. There were holes in my background from having completed my undergrad at a small university, which made things tough. My courses in grad school were fairly traditional with very little instructor-student interaction, and I found it hard to ask questions and collaborate with my peers. When I did go to office hours, I often left feeling as though my questions had been stupid, and feeling dumb all of the time wasn't exactly fun or motivating.

There were some exceptions, though:

I had an unofficial faculty teaching mentor who encouraged me to think for myself, put forth my ideas and, in general, try stuff (i.e. do all of the things my undergrad instructors had encouraged me to do when I was learning math, but now in the context of teaching math). $\mathrm{He}$ challenged the way I thought about teaching and helped me navigate my way through difficulties. He created an environment in which my opinion was valued and respected, and there was a strong sense of collaboration in our teaching group-feedback would often be put into action. I can remember having an idea about changing the overall structure of a pair of courses I was teaching, and this actually got put into effect. Having the opportunity to make mistakes in a supported environment was paramount to my growth and identity as an educator. I am realizing how lucky I was to have had such a supportive teaching mentor throughout grad school. For 
me, it seems to have worked out completely by serendipity that I ended up in that situation. Somehow, I ended up working as a workshop TA from day one (this was highly unusual) and with a faculty member who was very passionate about teaching. A lot of the opportunities that I received were a direct consequence of that.

In my second reflection, I expand on the difficulty of turning away from a research career, and how important it was for me to be able to start thinking about this early in my graduate degree:

I think I knew at some point during my first two years of grad school (when I was a master's student) that I was more interested in teaching than "normal". I worked as a calculus workshop TA during those years, and I remember enjoying talking about mathematics with the undergraduate students and helping them have a more authentic math experience (using creativity and reasoning to work through a problem rather than blindly applying a formula). It was a fun space, and a stark contrast to how I felt about my own studies and research at the time. I became aware of the fact that I'd choose to work on any teaching-related work I had before my own coursework or research whenever I sat down to get something done, and I think that helped me realize where my true interests were. I found it hard to let go of the idea that I'd be some sort of researcher because, going into grad school, that's what I thought the end goal of grad school was.

\section{Matt: Sustained by Proximity}

Of the three participant-researchers, my journey in the landscape, marked in orange in Figure 2, was the most wide-ranging. I marked, tutored, facilitated labs, and ran workshops before receiving my first teaching assignment. My first reflection depicts scenes from my development as an instructor. In the early scenes, I am someone who has thought deeply about his subject, but not about how it is taught:

In my first year of grad school I did some marking for a second-year ODE [ordinary differential equations] course. I talked with the instructor once or twice throughout the term and sent a few emails to let them know what the students were messing up. I also held office hours each week but only once received students. The two students who came to visit me wanted to know about proof by induction. I berated them for not being at the same level I was when I was their age: "What do you mean you didn't learn proof by induction in high school?!" To my disappointment, they thought it was a technique that was specific to Laplace transforms. I felt it was my duty to tell them how beautiful, important, and far-reaching the technique is.

Later that year I was TAing a MATLAB lab. [...] In the last lab of the year I figured I would show them something a little deeper. I asked the class if they "wanted me to explain how the page rank algorithm actually works" (rather than just implement it). There were a few keen nods from the front but mostly the class continued to chat among themselves. Only a few students were listening, and I don't think they were able to follow. At 
this point, my idea of an effective instructor was one who could lecture in an engaging way and whose allegiance was to mathematics.

Around this point, as in Vanessa's journey, the scenes change slightly. Students enter the picture-not as obstacles to the subject but as living, thinking individuals:

I was a workshop TA at the time. Students would solve a problem in groups at the board while I circulated and facilitated. We had weekly meetings with the instructor in charge of the course. We talked about the previous week: What did the students struggle with and how did you respond? We talked about the week to come: Do we understand the math and where do we think the students will get stuck? This is where I learned to facilitate. I remember having a lot of heated and exciting conversations. Sometimes we would just complain about the students, but then we would try to figure out why students would say the things they say. Because of the group, we kept pushing each other. I started to find myself thinking about our conversations on the bus ride home.

The community was the key: "Because of the group, we kept pushing each other". In my second reflection, I ask whether it would have been possible to have had a similar community when I was marking an upper year course in my first term as a graduate student:

I'm not sure what a community of markers would look like, but maybe just a community is good enough. The key conversations I had as a workshop TA were mostly around planning and reflection. There was also kind of a phase transition where one goes from complaining about students, so asking questions like "Why don't they see this!" to thinking productively about student learning, "When students say/write this, what does it mean about their understanding?"

I also point out that the community kept talking even when our shared TAship was over:

Once I found community, it was sustained by itself_-or at least sustained by proximity. I was a workshop TA with my officemates one year and we talked a lot about teaching together outside of our weekly meetings. The next year, we all had disparate TAships, but still talked together about the challenges we were experiencing and the opinions we were developing about philosophy of teaching and learning. This just happened spontaneously because we were all in the office together and experts at procrastination.

\section{Discussion: Community, Luck, and Policy}

\section{Community}

We began this project with the idea that the three participant-researchers' reflections would reveal insights about innovation, mentorship, and expectations. While the reflections did comment on these, the theme that emerged from all three had to do with the importance of community in the development of a young instructor's identity.

Vanessa's turning point is finding, a year into her Master's degree, "a group of graduate students led by a faculty member, with the common goal of 
enhancing the learning experiences of their students." She is clear about how subversive and liberating this is: "I don't think I had the time to pursue things on my own until someone reached out, because I was trying to be what everyone else was."

Similarly, the community that Pam finds through her "unofficial faculty teaching mentor" transforms her journey. She writes: "I felt a sense of belonging in this teaching group in a way I no longer did in the math community, and my focus shifted from learning math to helping people learn math."

For Matt, finding a community changes his teaching and his teaching philosophy:

At the end of the year, I collected all my notes from our group discussions and used them to write a teaching philosophy. It included lines like: "When the instructor stops speaking, the students start thinking." I was also trying to bring the notion of community into my classroom: "If a student asks a question, I open it to the class and ask: 'Can we figure this out together?"”

The importance of community is well-documented in the research literature on graduate student well-being and mental health. A recent study found that "graduate students are more than six times as likely to experience depression and anxiety as compared to the general population" (Evans et al., 2018, p. 282). A related working paper (Barreira et al., 2018) describes an overwhelming sense of alienation and drift. These results are matched in a study of a large graduate student population in the Netherlands, where 32\% were found to be at risk of depression (Levecque et al., 2017). A report on Science and Engineering graduate students at Berkeley puts the number even higher, at 43-46\% (Graduate Assembly, 2014).

The data indicate that graduate students are driven to worry about virtually everything. They worry about making a bad impression on their supervisor, about their career trajectory, about raising their hand in a seminar, about whether their work is too difficult, or too easy. The experience that Vanessa recounts in her reflection, of systematically removing every activity but research from her life, is not uncommon. Open communication, supportive colleagues and strong communities are proposed in all the papers cited above.

\section{Luck}

Luck plays a major role in all three participantresearchers' abilities to find communities. In each case, the community seems to emerge accidentally, whether it is through someone reaching out with encouragement (Vanessa), the help of an informal faculty mentor (Pam), or simply being in close proximity with colleagues (Matt).

In her reflection, Pam registers the role of luck in her own journey and diagnoses the injustice of the situation:

Towards the end of my graduate studies and now as a junior lecturer, I am realizing how lucky I was to have had such a supportive teaching mentor throughout grad school. At the same time, I think it's sad that I feel lucky—shouldn't all interested math grad students get the opportunities and support that I had?

Even if the support eventually appears, timing is critical. Pam goes on:

I know several of my fellow graduate students had very different experiences. One student, when he was teaching for the first time, received very little mentorship from the instructor-in-charge... He didn't enjoy the experience. Later, when he worked as a TA with a more handson instructor-in-charge, he had a much more enjoyable experience and got very positive feedback from his students. Through this TAship, he got a better idea of what he should have done in the class and thought about changes he would make if he got the opportunity to teach again. 


\section{Policy}

We believe that good policies nudge the landscape so that the people on the landscape depend less on luck. In each of the following subsections, each participant-researcher revisits their reflection, identifies a pivotal marker, and then asks: What are the critical details at that marker? And can a similar marker be placed in the landscape in a location where others can benefit from it?

\section{Vanessa's Idea: Instructional Skills Workshops for Drop-in Tutors}

After finding that initial community of graduate students interested in student-centred learning, I took an Instructional Skills Workshop (ISW), a three-day session on student-centred lesson planning that integrated me even more into the teaching community. Integration into a community is well understood to be a crucial ingredient in teacher development in general (Beck \& Kosnik, 2001), and TA development in particular (Milner-Bolotin, 2001).

It was important for me to have this opportunity early in my journey. The ISW, like most of the components of the training program described in The Landscape of TAship section, is designed for instructors. TAs who choose to take it tend to do so relatively late in their career, with classroom teaching explicitly in mind. Those students not immediately interested in classroom teaching are unlikely to encounter the ISW. They miss out on the opportunity that was pivotal for me.

I propose that a version of the ISW be designed explicitly for TAs assigned to work in the drop-in tutorial centre. The structure of the ISW is flexible enough to accommodate this. In fact, the centrepiece of the ISW is a series of 10-minute minilessons given by participants to other participants. They are meant to simulate lessons in miniature, and participants are encouraged to try out student-centred teaching techniques. An ISW for tutoring TAs would have the additional benefit of authenticity: a typical interaction in the tutorial centre is actually around 10 minutes long, and involves all of the features-a bridge-in to the main lesson; an objective, declared by the student and possibly tweaked by the TA; a pretest to determine the student's prior knowledge; participation by the student; and so on-that are promoted by the ISW.

A tutor-focused ISW could benefit many students in the crucial early stages of their journeys. Tutoring TAships are the most common first assignments, and drop-in tutorial centres are a feature of many North American Mathematics departments.

\section{Pam's Idea: Mentorship Roles for Leader TAs}

The community that I depict in my reflections is the pairing of a student and her mentor. Generally, mentoring of students at the graduate level is an effective (Holley \& Caldwell, 2012) and imperative (Davidson \& Foster-Johnson, 2001; Lyons, Scroggins, \& Bonham Rule, 1990) practice-one that "play[s] an important role in students' decisions to enroll and persist in graduate studies" (Herzig, 2004, p.380). An unavoidable issue with mentorship is that it is expensive in terms of human resources. However, features of mentorship may be captured in other forms.

I propose that senior graduate students assigned leader TAships (as described in Table 1) be provided with resources to mentor other students. Currently, leader TAs are essentially administrators: they schedule other TAs, run weekly meetings to make sure TAs are on track, and perform important clerical tasks like scanning and sorting quizzes. Some of these tasks can be passed on to other TAs; this is an increase in resources, but a modest one compared to asking faculty members to be mentors.

In place of these duties, I propose that the leader TA use some time in regular meetings to guide short discussions around a list of questions designed to lead TAs through a reflective exercise as the term progresses. For example, for a TA leading other workshop TAs, the question one week might be, "What do you think your students will find most challenging in next week's workshop, and how will you help them navigate that challenge?" The following week, the questions might be "Did you anticipate the challenge correctly? Were your strategies successful?" I anticipate that the leader 
TAs, who are already selected on the basis of their interpersonal strengths, would flourish in this expanded role.

At some point, most TAs are assigned to be a workshop or co-teaching TA. In the landscape illustrated in Figure 1,100 of the 146 TAs represented passed through the workshop or co-teaching node. The significant opportunity that I received was the mentorship that came along with the TAship, and it was critical that this came early in my journey. Allowing leader TAs to be mentors themselves spreads the opportunity around and allows for more TAs to have meaningful opportunities early in their program.

Matt's Idea: Assign the Same TAship to TAs in the Same Office

The community that I describe in my reflections is the most accidental of all: I happen to have the same TAship as my office mates, so we talk about teaching: "This just happened spontaneously because we were all in the office together and experts at procrastination." This phenomenon is well-known, if not broadly promoted. In their 2009 paper, Roxå and Mårtensson describe the importance of "significant networks" in university teaching: small, high-trust and intellectually compatible groups of practitioners. One of their subjects describes the experience of having important conversations about teaching that "originate in different situations and different contexts where the topic of discussion initially might have been another, and, consequently [...] are spontaneous" (Roxå \& Mårtensson, 2009, p. 553).

I propose a light intervention with broad potential impact: simply assign the same type of TAship to TAs in the same office. Beyond the benefits of having TAs talk to each other about teaching, it is plain to us that graduate students want to connect-and the research on graduate student communities summarized in section 4.1 indicates that this should be strongly encouraged.

To take a recent example, only 23 of the 141 TAships assigned in the fall term of 2018 were held by TAs in the same office. There are logistical obstacles to increasing this ratio-for instance, TAs are generally assigned office space by research group, which is not always compatible with the proposed intervention-but even doubling the ratio would go a long way to promoting the kind of "accidental community" I describe in my reflections.

\section{Closing Remarks}

The proposals made are possible because of both the bird's-eye perspective and the views from the ground. The ideas behind the proposals emerge from the views of the three participant-researchers on the ground. The proposals themselves are built around the bird's-eye view of common experiences in our departmental context. Vanessa's idea of ISWs for tutor TAs will benefit graduate students because we can see in the bird's-eye view that many TAs work early and frequently in the tutorial centre. Pam's idea of giving leader TAs small mentorship roles makes sense because we can see that this would impact a small number of TAships but a large number of TAs. Matt's idea of assigning TAships to TAs in the same office has the potential for impact because we can see that this does not already happen.

Though we situate our research in a Mathematics department, our conclusions are broader. The three journeys pictured in Figure 2 vary widely: all the nodes are visited, but only one nodethe "teaching" node-is visited by all three participant-researchers. Nevertheless, the theme of "community" emerged distinctly in all three reflections.

We encourage all departments to listen to the stories of their own graduate students and try to understand their experiences. Harnessing the energy of graduate students to build communities is a theme of established research (Milner-Bolotin, 2001). We encourage harnessing their insight as well. We hope our recommendations increase the likelihood that graduate students will encounter focused, impactful support early in their careers. Our reflections indicate that a little can go a long way. As Vanessa writes:

Being driven and self-motivated is definitely a large part of the picture, 
but I don't think I would have been as driven if I didn't have that one person show interest and support. Once there was an opening, I started taking small steps to explore what I could do in this new domain.

\section{References}

Barreira, P., Basilico, M., \& Bolotnyy, V. (2018). Graduate Student Mental Health: Lessons from American Economics Departments. Working paper. Retrieved from https://scholar.harvard.edu/bolotnyy/publi cations/graduate-student-mental-healthlessons-american-economics-departments

Beck, C., \& Kosnik, C. (2001). From cohort to community in a preservice teacher education program. Teaching and teacher education, 17(8), 925-948.

Bogdan, R., \& Bicklen, S. (2007). Qualitative research for education: An introduction to theories and methods (5 ${ }^{\text {th }}$ Ed.). Boston: Pearson.

Boyle, P., \& Boice, B. (1998). Systematic mentoring for new faculty teachers and graduate teaching assistants. Innovative Higher Education, 22(3), 157-179. Retrieved from https://link.springer.com/article/10.1023/ A:1025183225886

Bruni, C., \& Leung, F. (2020). Authentic experiences in two graduate instructor training courses. Syllabus, to appear.

Davidson, M. \& Foster-Johnson, L. (2001). Mentoring in the preparation of graduate researchers of color. Review of Educational Research, 71(4), 549-574. Retrieved from https://journals.sagepub.com/doi/abs/10. $\underline{3102 / 00346543071004549}$

Dawson, D., Borin, P., Meadows, K., Britnell, J., Olsen, K., \& McIntyre, G. (2014). The impact of the Instructional Skills Workshop on faculty approaches to teaching. Toronto: Higher Education Quality Council of Ontario. Retrieved from http://www.heqco.ca/SiteCollectionDocu ments/Formatted UWO Ryerson.pdf

Ellis, C. (2004). The ethnographic I: A methodological novel about autoethnography. Walnut Creek, CA: Rowman and Littlefield Publishers.

Ellis, C. \& Bochner, A. P. (2000). Autoethnography, personal narrative, reflexivity. In N. K. Denzin \& Y. S. Lincoln (Eds.), Handbook of qualitative research (2nd Ed.) (pp. 733- 68). Thousand Oaks, CA: Sage Publications.

Ellis, J. (2014). Preparing Future College Instructors: The Role of Graduate Student Teaching Assistants (GTAs) in Successful College Calculus Programs (Doctoral dissertation UC San Diego, CA). Retrieved from https://escholarship.org/uc/item/9b5813s $\underline{5}$

Evans, T., Bira, L., Gastelum, J., Weiss, L., \& Vanderford, N. (2018). Evidence for a mental health crisis in graduate education. Nature Biotechnology, 36, 282-284. Retrieved from

https://www.nature.com/articles/nbt.4089

Graduate Assembly Graduate Student Happiness and Well-Being Report (2014). Retrieved from http://ga.berkeley.edu/wpcontent/uploads/2015/04/wellbeingreport 2014.pdf

Hayano, D. (1979). Auto-ethnography: Paradigms, problems, and prospects. Human Organization, 38, 113-120. Retrieved from https://sfaajournals.net/doi/abs/10.17730 Lhumo.38.1.u761n5601t4g318v?journalCod $\underline{\mathrm{e}=\text { humo }}$

Herzig, A. (2004). 'Slaughtering this beautiful math': graduate women choosing and leaving mathematics. Gender \& Education, 16(3), 379- 
395. Retrieved from

https://www.tandfonline.com/doi/abs/10. $\underline{1080 / 09540250042000251506}$

Holley, K. \& Caldwell, M. (2012). The Challenges of Designing and Implementing a Doctoral Student Mentoring Program. Innovative Higher Education, 37, 243-253. Retrieved from https://link.springer.com/article/10.1007/s 10755-011-9203-y

Levecque, K., Anseel, F., De Beuckelaer, A., Van der Heyden, J., \& Gisle, L. (2017). Work organization and mental health problems in PhD students. Research Policy, 46(4), 868-879.

Retrieved

from https://www.sciencedirect.com/science/art icle/pii/S0048733317300422

Lyons, W., Scroggins, D. \& Bonham Rule, P. (1990). The mentor in graduate education. Studies in Higher Education, 15(3), 277-285. Retrieved from

https://www.tandfonline.com/doi/abs/10. $\underline{1080 / 03075079012331377400}$

Milner-Bolotin, M. (2001). Creating community among the graduate teaching assistants: Benefits, challenges, and lessons learned. Journal of Graduate Teaching Assistant Development, 8(2), 65-70.

Musgrave, S., \& Carlson, M. P. (2017). Understanding and advancing graduate teaching assistants' mathematical knowledge for teaching. The Journal of Mathematical Behavior, 45, 137-149. Retrieved from https://asu.pure.elsevier.com/en/publicatio ns/understanding-and-advancing-graduateteaching-assistants-mathemat

Silverman, S. (2003). The role of teaching in the preparation of future faculty. Quest, 55(1), 7281. Retrieved from https://www.tandfonline.com/doi/abs/10. $\underline{1080 / 00336297.2003 .10491790}$
Speer, N., Gutmann, T., \& Murphy, T. J. (2005). Mathematics teaching assistant preparation and development. College Teaching, 53(2), 7580. Retrieved from https://www.tandfonline.com/doi/abs/10. $\underline{3200 / C T C H .53 .2 .75-80}$

Wall, S. (2008). Easier Said than Done: Writing an Autoethnography. International Journal of Qualitative Methods, 7(1), 38-53. Retrieved from

https://journals.sagepub.com/doi/10.1177 $\not 160940690800700103$

\section{Biographies}

Matt Coles is a Science Education Specialist in the Mathematics Department at the University of British Columbia where he works on curriculum renewal and instructor professional development.

Fok-Shuen Leung is a faculty member in the Mathematics Department and Academic Director, First Year Experience at the University of British Columbia.

Vanessa Radzimski is an Assistant Professor in Mathematics at the University of the Fraser Valley, where she researches the role of advanced mathematics coursework for future secondary math teachers.

Pam Sargent is an Assistant Professor in the Department of Mathematics and Statistics at York University where she works on Mathematics Education. 